W. H. AUDEN

Lectures on

Shakespeare 
W. H. AUDEN: CRITICAL EDITIONS

GENERAL EDITOR

Edward Mendelson

Juvenilia: Poems, 1922-1928

Edited by Katherine Bucknell

Lectures on Shakespeare

Reconstructed and edited by Arthur Kirsch 


\title{
W. H. AUDEN
}

\section{Lectures on}

\section{Shakespeare}

\author{
REGONSTRUCTED AND \\ EDITED BY \\ Arthur Kirsch
}

With a new preface by the editor

\author{
PRINCETON UNIVERSITY PRESS \\ PRINCETON AND OXFORD
}


Preface copyright () 2019 by Arthur Kirsch

Introduction and notes, copyright ( 92000 by Arthur Kirsch

Lectures and all writings by W. H. Auden,

copyright $\odot 2000$ by The Estate of W. H. Auden

Not to be reprinted without permission

Published by Princeton University Press, 41 William Street,

Princeton, New Jersey 08540

Cover image: W.H. Auden, ca. 1946. Photo by Jerry Cooke/

The LIFE Picture Collection/Getty Images

\section{All Rights Reserved}

Fourth printing, and first paperback printing, 2002

First Princeton Classics paperback printing, with a new preface by the editor, 2019

Paperback ISBN 978-0-691-10282-5

Library of Congress Control Number:2019944458

This book has been composed in Baskerville

Printed on acid-free paper. $\infty$

press.princeton.edu

Printed in the United States of America 